\title{
Chinese Subsidies in Economic Development: the Case of the Jamaica Logistics Hub
}

\author{
Kimberly Chin \\ School of Management \\ Wuhan University of Technology \\ Wuhan, China \\ Kymchyn@hotmail.com
}

\begin{abstract}
Chinese investment will have on the proposed logistics hub and its impending economic development for Jamaica. There is uneasiness about the discloser of government's negotiation proceedings with China Engineering Harbour Company (CHEC), the company selected to undertake the development project. The main concerns are environmental risk and guarantee of economic advantage. Chinese environmental and social sustainability standards are not comparatively reconciled with those of the World Bank, the governing body of such standards in the western hemisphere. The paper indicates actions the government should take to safeguard itself from reliving past experiences where promised economic development through foreign subsidiaries proved more advantageous to the foreign investors than the economy. It also proposes and unbiased outline of upgrading Chinese investment projects to reconcile its environment and social standards with those of the western hemisphere (The World Bank).
\end{abstract}

Keywords-Economic growth; Foreign subsidies; Environmental policy; International legislation; Employment for Skilled and Unskilled Workers.

\section{INTRODUCTION}

In 2013, the government of Jamaica disclosed plans to contract China Harbour Engineering Company (CHEC) to operate the transshipment port for the proposed logistics hub in Jamaica. The transshipment port location selected is the Goat Islands, a natural reserve in the Portland Bight area under the Natural Resource Reservation Authority (NRRA). This sparked an immediate response from environmentalists and the general public with concerns about the threat of natural disasters, national land use planning and displacement of persons who support their livelihoods from the fishing industry in that area.

The apprehension stems from the appearance that the government accepted commitment with China without a mandated environmental impact assessment. This assessment proves most important as it reveals that there are disparities in environmental guidelines between Chinese financial institutions and the World Bank. Tufts University reports that "Major infrastructure and heavy industry projects have the potential to create environmental problems in Latin America $\&$ the Caribbean (LAC). In response to civil society efforts to "green" the development banks, many Western banks now have significant environmental guidelines. China has developed similar environmental guidelines for its development banks. However, comparison of those guidelines finds that, despite significant progress in the past decade, China's guidelines do not yet match those of its Western counterparts."

A paper published by the Caribbean Policy Research Institute (CaPRI) it states "It is very unlikely that the Jamaica Logistics Hub will automatically create wealth in Jamaica. This is because the country currently does not specialize in areas of service provisions typically associated with logistics operations and is outperformed in three key components of the logistics environment by most of the potential regional competitors." This indicates that the prospect of economic progression is one that is not immediate but will require extended endurance before achieving long-term benefits. Alternately, advocates for the transshipment port have countered the concerns as being secondary to the expected economic benefits. It begs the question what are Jamaicans expected to do in lieu of these promised benefits? Another hesitation is the fact that details of the agreement between CHEC and the government has been precariously classified. There has been no official information released to adequately inform the country of the government's plans. This hesitation is a source of anxiety for Jamaicans as they have experienced artificial benefits that in reality did not function in their favour.

The Chinese government in recent times has built tremendous momentum in strengthening its diplomatic ties between the Caribbean, Africa, specifically in areas of ecological sensitivity. According to Richard Bernal "Chinese companies have initiated ventures in more than a dozen Caribbean countries. Cuba, Guyana, Suriname and Jamaica stand out as the most important destinations for investment." With the imminent fiscal advantage Jamaica has as being the host of the logistics hub for the entire western hemisphere it is no surprise that the incentive to increase foreign direct investment in Jamaica would be significantly higher than the rest of the Caribbean.

In the final analysis, a conclusion on the impact of CHEC's agreement with the government will be settled on and directives to guarantee Jamaica's environmental protection and significant economic benefits will be produced. 


\section{Methodology}

This paper used secondary data from published articles on government websites as well as extracted econometric results from surveys. The surveys were analysed using SPSS statistical software and incorporate the use of ANOVA and descriptive statistics. Published articles on the government websites were very instrumental in gathering information as many critiques, commentaries and research editorials illustration mixed angles on the proposed logistics' initiative. Additionally, informal interviews were conducted in the form of email correspondence to professional associated with the venture to gather unpublished information that are not readily available online.

\section{ENVIRONMENT ProteCtion VS ECONOMIC AdVANTAGE}

At the announcement of the government's plans to lease the Goat Islands to CHEC for construction of transshipment hub and industrial and commercial zones, the environmental activist have expressed concerns about the threat to the ecological balance within the area of Goat Islands. The area, which is a natural reserve and protected area and sanctuary stands to compromise marine life, through potential oil spills and other harmful hazards, environmentalists argue that the Environmental Management Scope Report (EMSR) was inadequately conducted and contained many errors that overlooked the biodiversity of the area. Alternatives to relocate the natural reserve have proved problematic as environmental conditions have not shown evidence of a carbon copy location. Additionally, the Portland Bight is a source of livelihood for approximately 4000 families. The displacement of their source of employment will be compromised and alternate occupations have not been directly indicated to them.

According to Pinnock and Ajagunna 2012 in a presentation "From Piracy to Transshipment: Jamaica's Journey to becoming a Global Logistics Hub" environmental awareness has influenced sustainable business practices in Jamaica since the 1970's. Considerations for natural resources and the environment are understood to be crucial in business decisions and this awareness is also influential in the logistics sector. This indicates that the concerns raised about the environmental impact will not be ignored and will have high influence in the plans to construct the hub going forward. In response to the potential loss of livelihood of the residents in the Portland Bight Area, the government has partnered with the Caribbean Maritime Institute to enlist citizens to get certified in areas related to logistics operations such as crane and equipment operators, lines men, maintenance technicians and mechanical and electronic engineers.

CHEC is the Chinese engineering company contracted to construct the logistics hub. There are concerns from the general public that Chinese investors do not maintain international standards on environmental safety. The leading Chinese lending institutions involved in Chinese FDI are China Development Bank and China Export-Import Bank (EximBank). These institutions promote, institute and implement environmental and social policies to diminish unpredicted environmental and social damage that would otherwise undercut the long-term success of a development project.

Contrastingly, The World Bank Group developed "safeguard" policies which required borrowers conduct social and environmental assessment and consult local communities. Between 1996 - 2006 they have employed additional bodies such as The World Bank Inspection Panel and the Compliance Advisory Ombudsman (CAO), which have similar responsibilities to investigate projects funded by associations within The World Bank Group except; that the CAO specifically deals with complaints occurring within these projects. Additionally, the body derives solutions and alternatives to the benefit of protecting environment and social policies, Chinese investors to date have not shown signs of having such supporting regulating bodies that are clearly necessary and sustainable to a process and system focused on preserving environmental and social policies best interest.

Economically, the transshipment port is poised to furnish a host of benefits to ordinary Jamaicans in the way of job provision, foreign currency and international competitiveness. The core function of a logistics hub is to handle distribution and development (economic zones) of cargo to be shipped to the entire western hemisphere, an 800 million market. The event that necessitated a hub initiative came from the expansion of the Panama Canal which intended to accommodate increased shipping vessel traffic. The initiative calls for the development of Jamaica's logistics infrastructure in transport, aviation and maritime. The critical benefit of the initiative stimulates our local commercial and industrial markets. Micro Small and Medium Enterprises (MSME) will gain an opportunity to position themselves to connect with global markets for trade, supply and investment. The general public has expressed skepticism about the proposed economic benefit the initiative promotes. A survey was conducted to determine whether-based on a forecast - if the logistics hub initiative will provide the economic prosperity it promises. Data from economic growth reports derived from past foreign subsidiaries were compared to the pending logistics venture and its proposed benefits were correlated in SPSS as a means to determine if there was a significant relationship between past ventures of this nature. The hypothesis assumes that the logistics hub initiative to economic benefit is likely to bear high rate of risks at the expense of beneficiary populations' interests. To assess the hypothesis the ANOVA test is run to determine the theory. $\mathrm{HO}$ represents the null hypothesis and $\mathrm{H} 1$ is the alternative hypothesis. 
TABLE I. ANOVA WITH COCHRAN'S TEST

\begin{tabular}{|l|c|c|c|c|c|}
\hline & Sum of Squares & df & Mean Square & Cochran's Q & Sig \\
\hline Between People & & 117 & & & \\
Within People Between Items & 67.500 & 8 & .356 & & \\
& 215.576 & 1523 & 21.830 & 560.506 & .000 \\
& 317.343 & 1423 & .333 & & \\
Residual & 528.000 & 1598 & .356 & & \\
Total & 615.700 & .362 & & \\
& & \multicolumn{3}{|c|}{ Grand Mean $=1.7000$}
\end{tabular}

The analysis of variance (ANOVA), with a Cochran's Q of 560.506 (table 1), revealed that the p-value equal to .000 is statistically highly significant because it is less than 0.05 . This mean all the variables are important to perform our study.

Panama has partnered with Jamaica to develop the island's initiative to construct a world class logistics hub with infrastructure, legislation and technology of international quality. The partnership is focus on improving Jamaica's performance in trade, services, custom regulations and investment. They are determined to build up Jamaica's momentum in performance to match the efficiency and operations pace of the rest of Central and Latin America and North America. The hypothesis queries foreign partnerships with Jamaica and its impact in economic performance.

H0 - Foreign partnerships have not resulted in a significant sustainable growth of the economic performance.

H1 - Foreign partnerships has led to increasing outputs of countries' economy.

TABLE II. FOREIGN FINANCIAL AID

\begin{tabular}{|l|c|c|c|}
\hline & Observed $\boldsymbol{N}$ & Expected $\boldsymbol{N}$ & Residual \\
\hline No & 42 & 58.7 & -16.7 \\
Not absolutely & 28 & 58.7 & -30.7 \\
Yes & 106 & 58.7 & 47.3 \\
Total & 176 & & \\
\hline
\end{tabular}

Here we clearly see that the p-value is .000 at a significance level of $5 \%$ or .05 . The p-value .000 is less than .05 , meaning that the null hypothesis can confidently be rejected. It is important to note that partnerships are important to increase the performance capabilities which will directly translate to financial benefit. The rejection of the null hypothesis and the consolidation of the alternative hypothesis are consistent with the economic performance.

\section{CONCLUSION}

Considering the arguments presented in the public sphere and the data analysis results it is evident that the logistics hub poses economic benefit from partnership with Panama but it is also evident that environmental concerns are still inadequately addressed. However, the conclusion of this paper determines that the following recommendations are necessary for the government of Jamaica to secure a balance of optimal benefits for both the economy and the environment:

1. Conduct a comprehensive assessment of the initiative in adherence to the national planning process for the environmentally protected area legislation. This assessment must comply and harmonize with Jamaica's international environmental commitments.

2. Establish an absolute account of the direct and indirect impact the initiative has on the environment and surrounding communities. It should also state the estimation of job provision, the required amount of skilled and qualified workforce and the total compensation for the potential loss of ecological services.

3. Considerations for a risk assessment climate change should be regarded in order to make adjustments in an ever changing, competitive environment. This helps to secure sustenance of competitiveness and performance.

4. It is important to expose potential hazards that may derive from construction of such a major project so that effective solutions can be agreed upon and should be settled before any industrial move is made.

5. Maintain transparency and carefully contemplate decision to be settled on. There is a hastening in the action plans to execute as soon as possible in an attempt to get an early advantage in the economic opportunity presented. The government should be careful of making hasty decisions as this could backfire and cause devastating effects resulting in a reverse expected outcome. It is equally as important for the government to make details of the agreement between itself and CHEC public so the country can understand the physical expectations and scope of the entire project.

\section{REFERENCES}

[1] "A useful overview of the functions of the compliance advisor/ombudsman (CAO)," 2009.

http://www.cao4ombudsman.org/about/

[2] Chinese statistical bulletin of outward foreign direct investment, 2011.

[3] O. Davies, "Statement 1.The protected chinese investment in the portland bight protected area," Statement to Parliament on Goat Islands, September 10, 2013.

[4] J. Francis, "Logistics hub may not benefit Jamaica - economist," Jamaica Gleaner. November 11, 2013.

[5] B. Henry, "Government dissmisses uncertainty about goat islands project," Jamaica Observer. May 15, 2014. http://goo.gl/zXb8OS

[6] A. Howell, M. Sun, and S. Hao, "Enironmental risks for major projects, London: European lawyer reference series," China in Moore, L. ed, pp 86,2012 . See also International finance corporation, preview: Green 
credit to bring international regulators, central bankers to Beijing, Wasington D.C.: World bank Group, 2012: http://goo.gl/zXb8OS

[7] Ibid. pp 20.

[8] "The Goat Islands/Portland bight protected area the proposed site for a transshipment port in Jamaica," Jamaica environmental trust, 2013.

[9] “Protected areas system master plan: Jamaica," NEPA, Governement of Jamaica, 2012.
[10] "Notice of the China banking regulatory commission CBRC on issuing the green credit guidelines," The China banking regulatory commission, Beijing, February 24, 2012. http://goo.gl/B5WzAX

[11] F. Pinnock and I. Ajagunna, "Caribbean maritime transportation sector: achieving sustainability through efficiency," Caribbean paper no. 12, Canada: centre for international governance and innovation (CIGI), 2012 